\title{
Efektifitas Penggunaan Reverse Osmosis Water dan Aquabidest dalam Meminimalkan Pertumbuhan Kuman di Humidifier pada Tindakan Terapi Oksigen
}

\author{
Effectiveness of the Use of Reverse Osmosis Water and Aquabidest in \\ Minimizing Germ Growth in Humidifiers on Oxygen Therapy Measures
}

\author{
M. SYAMSUL ARIF S.N \\ SARKUM \\ RODHI HARTONO
}

\author{
Jurusan Analis Kesehatan Poltekkes Kemenkes Semarang \\ Jl. Wolter Monginsidi Pedurungan Tengah Semarang \\ Email: Cepungmarupung@gmail.com
}

\begin{abstract}
Abstrak
Infeksi Oksigen merupakan kebutuhan dasar manusia yang tidak bisa ditunda pemenuhanya. Pada penderita yang mengalami hipoksia penatalaksanaan yang harus segera dilakukan adalah dengan terapi oksigen. Oksigen tabung cenderung bersifat kering sehingga dapat menyebabkan iritasi di sepanjang saluran pernapasan. Upaya guna meminimalkan permasalahan tersebut adalah dengan pemakain humidifier, namun penggunaan humidifier dapat sebagai tempat untuk pertumbuhan bakteri. Penelitian bertujuan mengetahui mana lebih efektif yang lebih efektif antara penggunaan reverse osmosis water dibandingkan dengan penggunaan aquabidest dalam meminimalkan pertumbuhan kuman di humidifier. Jenis penelitian adalah penelitian (true experiment) dengan rancangaan posttest control group design. Untuk mengetahui efektifitas pada kedua kelompok dilakukan dengan uji Mann-whitney. Terdapat perbedaan bermakna antara koloni kuman pada pengamatan jam ke 8, ke 16 dan jam ke, 24 pada kelompok aquabidest dengan $p$ value sebesar 0,018 dan kelompok Reverse osmosis water dengan $p$ value sebesar 0,007 . Tidak ada perbedaan bermakna koloni kuman pada kelompok aquabidest dengan Reverse Osmosis pada pengamatan jam ke 8 , ke 16 dan jam ke 24 dengan $p$ value secara berturut turut 1.00, 1,00 dan 0,74. Tidak ada perbedaan efektifitas antara penggunaan aquabidest dibandingkan dengan penggunaan Reverse Osmosis Water. Aquabidest dan atau Reverse Osmosis Water bisa digunakan di humidifier dengan menggunakan aquabidest dan reverse osmosis Water di humidifier pada tindakan terapi Oksigen.
\end{abstract}

Kata Kunci: Koloni Kuman ; Humidifier

\begin{abstract}
Oxygen is a basic human need that cannot be delayed. In patients who experience hypoxia management that must be done immediately is oxygen therapy. Oxygen tubes tend to be dry so they can cause irritation along the respiratory tract. Efforts to minimize these problems are by using a humidifier, but the use of a humidifier can be a place for bacterial growth. The study aimed to find out which is more effective more effective between the use of reverse osmosis water compared to the use of aquabidest in minimizing germ growth in the humidifier. This type of research is research (true experiment) with the design of posttest control group design. To find out the effectiveness of the two groups, the Mann-Whitney test was conducted. There was a significant difference between the bacteria colonies at the 8th, 16th and hourly observations, 24 in the aquabidest group with a p value of 0.018 and the Reverse osmosis water group with a $p$ value of 0.007. There was no significant difference in bacterial colonies in the aquabidest group with Reverse Osmosis at the 8th, 16th and 24th
\end{abstract}


hours observations with $p$ values respectively $1.00,1.00$ and 0.74 . There was no difference in effectiveness between the use of aquabidest compared to the use of Reverse Osmosis Water. Aquabidest and / or Reverse Osmosis Water can be used in a humidifier by using aquabidest and reverse osmosis water in a humidifier on oxygen therapy.

Keyword: Bacteria Colonies ; Humidifier

\section{Pendahuluan}

Oksigen merupakan kebutuhan dasar manusia yang tidak bisa ditunda pemenuhanya. Pada penderita yang mengalami hipoksia penatalaksanaan yang harus segera dilakukan adalah dengan terapi oksigen. Menurut Smeltzer \& Bare (2010) Terapi oksigen merupakan pemberian oksigen pada pasien dengan kadar konsentrasi yang lebih tinggi dibandingkan dengan kadar konsentrasi oskigen pada lingkungan luar tubuh. Adapun tujuan pemberian terapi oksegen tersebut adalah untuk mencegah atau mengatasi hipoksia. (Perry \& Potter, 2010).

Oksigen yang berasal dari tabung cenderung bersifat kering sehingga sangat memungkinkan sebagai penyebab timbulnya iritasi sepanjang saluran pernapasan. Upaya yang dapat dilakukan guna meminimalkan permasalahan tersebut adalah dengan cara pemakain humidifier (Smeltzer \& Bare, 2010). Banyak pendapat bahwa penggunaan humidifier dapat sebagai tempat untuk pertumbuhan bakteri oleh karena media air bisa menjadi reservoir dalam pertumbuhan kuman (Scaffer, at al.1996).

Pencegahan pertumbuhan kuman pada humidifier yang dapat dilakukan perawat diberbagai rumah sakit diantaranya dengan melakukan desinfeksi terhadap tabung humidifier, air dalam humidifier harus air steril dan diganti setiap 24 jam, dan apabila bila cairan hendak ditambahkan sisa cairan harus dibuang terlebih dahulu (Nafisah, 2007). Hasil studi pendahuluan di ruang ICU beberapa rumah sakit mengisi humidifier menggunakan Aquabidest yaitu air steril buatan pabrik sehingga terbebas dari kuman. Sedangkan untuk ruang Hemodialisa sering menggunakan Reverse Osmosis Water.

Berdasar dari latar belakang tersebut di atas, maka peneliti tertarik untuk mengetahui efektifita penggunaan reverse osmosis water dan Aquabidest dalam meminimalkan pertumbuhan kuman di humidifier pada tindakan terapi oksigen.

\section{Metode}

Jenis penelitian yang peneliti gunakan adalah penelitian eksperimental (true experiment) yaitu penelitian yang memberikan perlakuan kepada obyek yang dapat mengendalikan variable dan secara tegas menyatakan adanya hubungan sebab akibat (Notoatmodjo, 2012).

Rancangan penelitian yang peneliti gunakan adalah posttest control group design dengan pengamatan berulang. Kelompok pertama adalah kelompok yang menggunakan Reverse osmosis water pada humidifier dan kelompok kedua adalah menggunakan Aquabidest steril pada humidifier.

Besar sampel ditentukan dengan rumus federer Berdasar dari hitungan maka setiap kelompok minimal menggunakan 16 tabung humidifier. Oleh karena terdapat dua kelompok, maka dalam penelitian ini diperlukan minimal 32 humidifier.

\section{Hasil dan Pembahasan}

\section{Hasil}

\section{Gambaran koloni kuman}

Gambaran koloni kuman berbagai pengamatan pada setiap kelompok disajikan pada tabel 4.1 dibawah ini 
Tabel 4.1. Gambaran koloni kuman pada pengamatan jam ke 8, jam kel6 dan jam ke 24. (n: 32)

\begin{tabular}{lccc}
\hline Kelompok & $\begin{array}{c}\text { Koloni } \\
\text { kuman } \\
\text { Pengamatan } \\
\text { jam ke } 8 \\
(\mathrm{X} \pm \mathrm{SD})\end{array}$ & $\begin{array}{c}\text { Koloni } \\
\text { kuman } \\
\text { Pengamatan } \\
\text { jam ke } 16 \\
(\mathrm{X} \pm \mathrm{SD})\end{array}$ & $\begin{array}{c}\text { Koloni kuman } \\
\text { Pengamatan jam } \\
\text { ke 24 } \\
(\mathrm{X} \pm \mathrm{SD})\end{array}$ \\
\hline $\begin{array}{l}\text { Penggunan } \\
\text { Reverse water }\end{array}$ & $0.00 \pm 0.00$ & $0.00 \pm 0.00$ & $\begin{array}{c}104.7 \pm \\
276,0\end{array}$ \\
\hline $\begin{array}{l}\text { Penggunaan } \\
\text { aquabidest }\end{array}$ & $0.00 \pm 0.00$ & $0.00 \pm$ & $890.6 \pm$ \\
\hline
\end{tabular}

Pada tabel di atas nampak bahwa ditemukan adanya koloni kuman pada pengamatan jam ke 24 baik pada kelompok penggunaan water reverse osmosis maupun penggunan aquabidest. Sedangkan pada pengamatan jam ke 8 dan jam ke 16 pada kedua kelompok tidak ditemukan adanya koloni kuman.

\section{Perbedaan Koloni Kuman Antar Kelompok}

Perbedaan rata rata koloni kuman antar kelompok pada setiap kali pengamatan dilakukan dengan uji mann whitney dilihat pada tabel 4.2 di bawah ini :

Tabel 4.2. Analisis perbedaan koloni kuman antar kelompok $(n=32)$

\begin{tabular}{lccc}
\hline \multicolumn{1}{c}{ Pengamatan } & $\begin{array}{c}\text { Penggunan } \\
\text { Reverse water } \\
(\mathrm{X} \pm \mathrm{SD})\end{array}$ & $\begin{array}{c}\text { Penggunan } \\
\text { Aquabidest } \\
(\mathrm{X} \pm \mathrm{SD})\end{array}$ & p value \\
\hline $\begin{array}{l}\text { Koloni kuman Pengamatan } \\
\text { jam ke 8 }\end{array}$ & $0,00 \pm 0.00$ & $0,00 \pm 0.00$ & 1.00 \\
\hline $\begin{array}{l}\text { Koloni kuman Pengamatan } \\
\text { jam ke 16 }\end{array}$ & $0,00 \pm 0.00$ & $0,00 \pm 0.00$ & 1.00 \\
\hline $\begin{array}{l}\text { Koloni kuman Pengamatan } \\
\text { jam ke 24 }\end{array}$ & $104.7 \pm 276,0$ & $89,6 \pm 226.5$ & 0.74 \\
\hline
\end{tabular}

\section{Ket : $(X \pm S D)$ dalam CFU/ml}

Seperti terlihat pada tabel di atas tampak $\mathrm{p}$ value $>0,05$ pada semua rata rata koloni kuman dari beberapa pengamatan. perbedaan koloni kuman pada pengamatan jam ke 8 dan pada pengamatan jam ke 16 antar kedua kelompok didapatkan $p$ value sebesar 1.00 . Sedangkan perbedaan koloni kuman untuk pengamatan pada jam ke 24 antar kedua kelompok nilai $p$ value 0.74 , sehingga dapat disimpulkan tidak ada perbedaan secara bermakna koloni kuman antar kedua kelompok.

\section{Pembahasan}

Secara kuantitatip pada pengamatan koloni kuman jam ke 8 dan pengamatan jam ke 16 tidak ditemukan koloni kuman baik itu pada kelompok penggunaan reverse osmosis maupun pada kelompok aquabidest. Sedang yang ditemukan adanya koloni kuman pada kedua kelompok hanya pada pengamatan jam ke 24 .

Menurut Sharah,dkk (2015) bahwa pembelahan kuman terjadi dalam hitungan jam dan terbagi dalam beberapa fase yaitu fase adaptasi, fase pertumbuhan cepat, fase stationer. Tidak 
ditemukanya koloni kuman pada pengamatan jam ke 8 dan jam ke 16 pada kedua kelompok kemungkinan karena apabila pada cairan humidifier terdapat kuman, kuman tersebut masih pada fase adaptasi, sehingga belum ada proses pembelahan kuman. Terdapat perbedaan bermakna jumlah kuman pada berbagai pengamatan, dimana pada pengamatan jam ke 24 dari hasil pemeriksaan tampak adanya jumlah kuman. pada jam ke 24 tersebut pertumbuhan kuman masuk dalam fase stationer setelah mengalami proses pembelahan cepat. Didukung oleh pernyataan Fauziah,dkk (2018) bahwa pertumbuhan kuman tercepat pada pernapasan berkisar sekitar 18 jam, sehingga pada jam ke 24 masuk fase stationer.

Dengan adanya ditemukan koloni kuman pada humidifier ke dua kelompok pada pengamatan jam ke 24, maka penggunaan humidifier yang berulang tanpa penggantian caiaran sangat beresiko terjadinya infeksi nosokomial. Didukung dari pernyataan Fauci, et al (2017) menyatakan bahwa penggunaan humidifier yang dipakai berulang sangat rentan terjadinya infeksi nosokomial dalam system pernapasan. Di perkuat oleh pernyataan Jadhav, et al (2017) bahwa infeksi nosokomial yang sering terjadi pada system pernapasan adalah pneumonia dan infeksi nosokomial ini salah satunya akibat penggunaan peralatan pernafasan diantaranya humidifier. Menurut Behnia,dkk (2014) menyatakan bahwa dampak infeksi nosokomial pada pernapasan bisa memacu morbiditas pasien. Dalam rangka meminimalkan kejadian infeksi nosokomial pada pernapasan, disarankan untuk penggantian cairan humidifier setiap 24 jam, penggunaan cairan humidifier lebih dari 24 banyak mengandung kuman (Nafisah ,2007). Secara prinsip bahwa pasien yang memerlukan terapi oksigen perlu pengggunaan humidifier secara tepat dan disesuaikan dengan kondisi klinis pasien. (Haitham \& Modrykamien, 2014)

Penggunaan reverse osmosis water dan penggunaan aquabidest sama baiknya dalam menghambat koloni kuman, dengan bukti tidak ditemukan adanya koloni kuman pada pengamatan jam ke 8 dan jam ke 16 pada kedua kelompok. Hal ini dikarenakan reverse osmosis water dan aquabidest merupakan air yang berkualitas baik untuk humidifier, sehingga pertumbuhan kuman dihambat. Reverse osmosis Water dihasilkan melalui proses hyperfiltration yaitu mekanisme filtrasi air dengan menggunakan membrane tanpa pori yang semi permeable. (Garud dkk, 2011). Menurut Winata (2016) proses filtrasi air dengan menggunakan membrane dengan ukuran 0,1 sd 10 mikrometer mampu memfilter kuman, apalagi reverse osmosis yang proses filtrasi air tanpa pori tentunya air yang dihasilkan sangat baik dan bebas dari kuman. Hasil penelitian yang dilakukan oleh Rica (2014) menyatakan bahwa air dari proses reverse osmosis tidak mengandung kuman E coli, sehingga aman untuk konsumsi. Dari penelitian tersebut bisa disimpulkan bahwa produk dari reverse osmosis terbebebas dari kuman. Sedangkan untuk aquabidest merupakan air dalam kemasan steril yang sudah dijamin tidak mengandung kuman.

Penyebab ditemukannya koloni kuman pada pengamatan jam ke 24 pada humidifier kedua kelompok bisa dikarenakan adanya proses kontaminasi humidifier tersebut. Sumber kontaminasi pada humidifier bisa berasal dari udara atau dari saluran pernapasan pasien. (Scaffer,et al 1996 dalam Zuhri, 2015). Kuman banyak terdapat dalam udara, apa lagi udara yang terdapat di rumah sakit yang merupakan lingkungan yang sangat terkontaminasi. Didukung dari pernyataan Boewers (2011) bahwa udara atau lingkungan atmsosfir yang sangat terkontaminasi tentunya sangat banyak terdapat kuman sehingga sangat merugikan kesehatan khususnya pada sistem pernapasan. Menurut Otter (2011) bahwa sumber kontaminasi lingkungan rumah sakit berasal dari pasien.

\section{Simpulan dan Saran}

\section{Simpulan}

Rata rata koloni kuman pada humidifier yang menggunakan aquabidest dari pengamatan jam ke 8, ke 16 dan ke 24 secara berurutan adalah $0.00 \mathrm{CFU} / \mathrm{mm} \quad 0.00$ $\mathrm{CFU} / \mathrm{mm}$ dan $89.6 \mathrm{CFU} / \mathrm{mm}$. Rata rata koloni kuman pada humidifier yang menggunakan Reverse Osmosis dari pengamatan jam ke 8, ke 16 dan ke 24 secara 
berurutan adalah $0.00 \mathrm{CFU} / \mathrm{mm} \quad 0.00 \mathrm{CFU} / \mathrm{mm}$ dan $104.7 \mathrm{CFU} / \mathrm{mm}$. Terdapat perbedaan bermakna koloni kuman pada humidifier menggunaan aqua bidest dari ketiga pengamatan dengan hasil uji Friedman didapatkan $\mathrm{p}$ value 0,018. Terdapat perbedaan bermakna koloni kuman pada humidifier menggunaan aqua bidest dari ketiga pengamatan dengan hasil uji Friedman didapatkan $\mathrm{p}$ value 0,007. Tidak ada perbedaan bermakna koloni kuman pada humidifier antara penggunaan aquabidest dengan penggunaan reverse dengan hasil uji mann-whitney didapatkan pada pengamatan jam ke 8 dan ke $16 \mathrm{p}$ value sebsar 1,00 dan pada pengamatan jam ke 24,p value sebesar 0,74.

\section{Saran}

Oleh karena Aquabidest dan Reverse osmosis water sama efektifnya dalam meminimalkan pertumbuhan kuman di humidifier, maka keduanya bisa digunakan sebagai cairan humidifier pada tindakan terapi oksigen.

\section{Daftar Pustaka}

Behnia M, Logan SC, Falen L, Catalano P. 2014 Nosocomial and ventilator-associated pneumonia in a community hospital intensive care unit: a retrospective review and analysis. BMC Res Notes. 11;7:232

Campbell, E.J., Baker, M.D., Crites, S.P. 2012. Subjective effects of humidification of oxygen for delivery by nasal cannula. A prospective study. Chest. 93(2). 298-93.

Culloch, J.M.C. 2000. Infection control: Science, management and practice. Philadelphia: Whurr publishers.

Fauci, G.B. Costa, A. Facciolà, A. Conti, R. Riso, and R. Squeri. 2017. Humidifiers for oxygen therapy: what risk for reusable and disposable devices? J Prev Med Hyg. 58(2): $161-165$.

Gibson, J.M. 1990. Modern microbiology and pathology for nurses.Oxford: Blackwell scientific publications.

Gould, D. \& Brooker, C. 2000. Applied microbiology for nurses, Basingstoke: Macmillan Press LTD.

Harahap, I.A. 2004. Terapi oksigen dalam asuhan keperawatan, http://library.usu.ac.id/download/fk_keperawatan-ikhsanuddin2.pdf diunduh 13 Agustus 2018.

Haitham S. Al Ashry and Ariel M. Modrykamien. 2014. Humidification during Mechanical Ventilation in the Adult Patient. Biomed Res Int. 2014- 715434

Handiyani, H. 2001. Hubungan antara waktu membersihkan ruangan dengan peningkatan jumlah mikroorganisme melalui aliran udara. Jurnal Keperawatan Indonesia. 5(2) 44-49.

Hilton, P.A. 2014. Breathing dalam Hilton, P.A. Fundamental Nursing Skills, hlm 14 Philadelphia: Whurr Publishers.

Hudak, C.M. \& Galo, B.M. 2012. Critical care nursing: A Holistik approach. Philadelphia: Lippincott Company.

Jadhav.S, Tushar Sahasrabudhe,Vipul Kaley, and Nageswari Gandham. 2013. The Microbial Colonization Profile of Respiratory Devices and the Significance of the Role of Disinfection: A Blinded Study. J Clin Diagn Res. 7(6): 1021-1026

Kalstrom, TJ. 2002. AARC clinical practice guideline: Oxygen therapy for adults in the acute care facility. Journal Respiratory Care. 47(6) 717-720. http://www.rcjournal.com/cpgs/pdf/06.02.717.pdf/ diunduh 17 Februari 2009.

Kozier, B., Erb, G., Berman, A., \& Snyder, S.J. 2004. Fundamentals ofnursing: concepts, process, and practice, 7 th ed. New Jersey: Person education

Kenji, M. 2004. Is it necessary to humidify inhaled low-flow oxygen or low concentration oxygen?. Journal of the japanese respiratory society. 42(2). 138-144.

Nafisah, S. 2017. pengaruh lama penggantian air humidifier lebih dari 24 jam terhadap pertumbuhan bakteri pada terapi oksigen system low flow low concentration di ruang 
rawat inap interna RSUD dr. Soebandi Jember. Skripsi untuk meraih sarjana keperawatan, Universitas Airlangga, Surabaya.

Notoatmodjo. S. 2005. Metodologi Penelitian Kesehatan.(cetakan ketiga). Jakarta: Rineka Cipta. Hal 88-89.

Otter JA, Yezli S, French GL 2011. The role played by contaminated surfaces in the transmission of nosocomial pathogens Infect Control Hosp Epidemiol. 32(7):687-99.

Pavlovic. 2000. Inhalation therapy- products for humidification and nebulisation, http://www.tycohealth-ece.com, diunduh 23 Agustus 2018.

Perry, A.G. \& Potter, P.A. 2010. Clinical nursing skills techniques. vol 2, 6thed. Australia: Elsevier-Mosby.

Perry, A.G. \& Potter, P.A. 2010. Fundamentals of nursing: Concepts, process, and practice. St. Louis: CV Mosby Company.

Rita, A.S. 2001. Terapi Oksigen dan Fisoterapi Napas Simposium Critical Care Nursing. Surabaya : Lab/ UPF Anestesiologi FK Unair- RSUD dr. Soetomo. Hal 1-10.

Sharah.A, Rahman Karnila, Desmelati. 2015. Pembuatan Kurva Pertumbuhan Bakteri Asam Laktat yang di Isolasi dari Ikan peda Kembung (rastrelliger sp.) JOM

Sastroasmoro, S. \& Ismail, S. 2008. Dasar-Dasar Metodologi Penelitian Klinis. (edisi 2). Jakarta: CV. Sagung Seto. Hal: 79, 220.

Scaffer, S.D., Burnett, C.B., Crowford, P.E., Duffy, J.R., Fontaine, D.K., dkk. 1996. Pocket guide to infection prevention and safe practice. Virginia: Mosby Year Book Inc.

Smeltzer, S.C. \& Bare, B.G. 2010. Brunner \& suddart's text book of medical- surgical nursing. Volume 1, ed 11th. Philladelpia: Lippincott.

Taylor, C., Cillis, C., \& LeMone, P. 2013. Fundamental of Nursing: The art and sience of nursing care. volume 2. (3th ed). Philadelphia: Lippincott.

Tucker, S.M., Canobbio, M.M., Paquette, E.V., \& Wells, M.F. 2000 Patient care standards; Collaborative planning \& nursing interventions. 7th. St. Louis: Mosby.

Uyainah, A. 2006. Terapi oksigen, dalam Sudoyo, A.W., Setiyohadi, B., Alwi, I., Simadibrata, M., Setiati, S., (edisi IV) Buku Ajar Ilmu Penyakit Dalam. (hlm. 125-127). Jakarta: PusatPenerbitan Deaprtemen Ilmu Penyakit Dalam Fakultas Kedokteran Universitas Indonesia.

Waugh J.B \& Granger W.M. 1998. An evaluation of 2 new devices for nasal high- flow gas therapy. Journal Respiratory care. 49(8):902-906.

Weber M.W., Palmer A., Jaffar S. \& Mulholland E.K. 2012. Diagnostic and Therapeutic Method Humidification of oxygen with unheated humidifiers in tropical climates. Journal Pediatric pulmonology. 22(2): 125-128.

Wenten. 2013. Teknologi Membran untuk pengolahan air [online]. http://www.igwenten.com/2013/02/teknologi-membran-untuk-pengelolaan-air.html diakses 12 September 2018

Yamashita, K., Nishivama, T., Yokoyama, T., Abe, H., Manabe, M. 2005. A comparison of the rate of bacterial contamination for prefilled disposable and reusable oxygenhumidifiers. J Crit Care. 20(2):172-5 